\title{
AZ-4217: A High Potency BACE Inhibitor Displaying Acute Central Efficacy in Different In Vivo Models and Reduced Amyloid Deposition in Tg2576 Mice
}

\author{
Susanna Eketjäll, ${ }^{1,2}$ Juliette Janson, ${ }^{1}$ Fredrik Jeppsson, ${ }^{1}$ Alexander Svanhagen, ${ }^{1}$ Karin Kolmodin, ${ }^{1}$ Susanne Gustavsson, ${ }^{1}$ \\ Ann-Cathrin Radesäter, ${ }^{1}$ Kristina Eliason, ${ }^{1}$ Sveinn Briem, ${ }^{1}$ Paulina Appelkvist, ${ }^{1}$ Camilla Niva, ${ }^{1}$ Anna-Lena Berg, ${ }^{1}$ \\ Sofia Karlström, ${ }^{1}$ Britt-Marie Swahn, ${ }^{1}$ and Johanna Fälting ${ }^{1}$ \\ ${ }^{1}$ Innovative Medicines AstraZeneca, CNS \& Pain, S-151 85 Södertälje, Sweden and ${ }^{2}$ AstraZeneca Translational Sciences Centre, Science for Life Laboratory, \\ S-171 65 Solna, Sweden
}

$\mathrm{A} \beta$, the product of APP (amyloid precursor protein), has been implicated in the pathophysiology of Alzheimer's disease (AD). $\beta$-Site APP cleaving enzyme1 (BACE1) is the enzyme initiating the processing of the APP to A $\beta$ peptides. Small molecule BACE1 inhibitors are expected to decrease $\mathrm{A} \beta$-peptide generation and thereby reduce amyloid plaque formation in the brain, a neuropathological hallmark of $\mathrm{AD}$. BACE1 inhibition thus addresses a key mechanism in $\mathrm{AD}$ and its potential as a therapeutic target is currently being addressed in clinical studies. Here, we report the discovery and the pharmacokinetic and pharmacodynamic properties of BACE1 inhibitor AZ-4217, a high potency compound ( $\mathrm{IC}_{50} 160 \mathrm{pm}$ in human SH-SY5Y cells) with an excellent in vivo efficacy. Central efficacy of BACE1 inhibition was observed after a single dose in C57BL/6 mice, guinea pigs, and in an APP transgenic mouse model of cerebral amyloidosis (Tg2576). Furthermore, we demonstrate that in a 1 month treatment paradigm BACE1 inhibition of $\mathrm{A} \beta$ production does lower amyloid deposition in 12-month-old Tg2576 mice. These results strongly support BACE1 inhibition as concretely impacting amyloid deposition and therefore potentially an important approach for therapeutic intervention in AD.

\section{Introduction}

Alzheimer's disease (AD) is a progressive neurodegenerative disorder manifested by cognitive deficits and impairment of activities of daily living. Abnormal amyloid accumulation as a result of changes in production, processing, and/or clearance of brain $\mathrm{A} \beta$ appear to be a critical event in the development of neuronal dysfunction, degeneration, and amyloid pathology in AD. Although our understanding of the molecular basis of the disease is increasing, there are no disease-modifying treatments (Ballard et al., 2011).

$\beta$-Site amyloid precursor protein (APP) cleaving enzyme1 (BACE1) and $\gamma$-secretase are involved in processing of the APP to $\mathrm{A} \beta$ peptides and have thus emerged as key targets for the treatment of AD (Vassar et al., 2009). Increased accumulation of A $\beta$ results in the formation of $\mathrm{A} \beta$ oligomers, cerebral amyloid

\footnotetext{
Received March 18, 2013; revised May 6, 2013; accepted May 6, 2013.

Author contributions:S.E., J.J., F.J., K.K., S.G., S.K., and B.-M.S. designed research;S.E., J.J., F.J., S.G., A.-C.R., K.E., S.B., P.A., and A.-L.B. performed research;S.E., J.J., F.J., and A.S. analyzed data; S.E., J.J., F.J., A.S., K.K., C.N., and J.F. wrote the paper.

This work was founded by AstraZeneca and all authors were at the time of the work employees of AstraZeneca. A special thanks to Daniel Bergström, Ann Staflund, and Anette Stålebring-Löwstedt for excellent animal husbandry and technical assistant. Kerstin Nilsson is acknowledged for statistical support and Anna Bogstedt for A $\beta$ measurements. Special thanks also to Eva Spennare for determining the fraction unbound in brain by the brain slice method and Jenny Johansson for measuring the plasma protein binding. Per-Olof Markgren and Karin Kaspersson are acknowledged for additional affinity measurements and for critical reading of this manuscript.

Correspondence should be addressed to Susanna Eketjäll, AstraZeneca Translational Sciences Centre, Science for Life Laboratory, S-171 65 Solna, Sweden. E-mail: Susanna.Eketjall@astrazeneca.com.

DOI:10.1523/JNEUROSCI.1165-13.2013

Copyright $\odot 2013$ the authors $\quad 0270-6474 / 13 / 3310075-10 \$ 15.00 / 0$
}

plaques, neurodegeneration, and brain atrophy (Hardy and Selkoe, 2002). Genetic mutations in APP have been associated with altered BACE1 activity with negative and positive implications for AD. APP with the Swedish mutation (K670N/M671L, $\mathrm{APP}_{\mathrm{SWE}}$ ) has a higher affinity for BACE1, increasing $\mathrm{A} \beta$ production and AD onset (Citron et al.; 1992). Recently, another variant of the APP gene (A673T) was reported. This substitution is located proximal to the BACE1 cleavage site and reduces BACE1 cleavage relative to wild-type APP (Jonsson et al., 2012). BACE1 knock-out mice confirmed the pivotal role of BACE1 in $\mathrm{A} \beta$ production by showing that production of $A \beta$ in brain was reduced (Roberds et al., 2001). The role of BACE1 in A $\beta$ plaque deposition is further supported by a study in which transgenic mice overexpressing human mutated APP crossed onto homozygous or heterozygous BACE1 knock-out mice display reduced A $\beta$ generation and plaque pathology (McConlogue et al., 2007).

BACE1 inhibitors are expected to reduce generation of $\mathrm{A} \beta$ and consequently decrease $\mathrm{A} \beta$ toxicity and the formation of amyloid plaques. Reduction of brain $\mathrm{A} \beta$ levels after administration of BACE1 inhibitors have been demonstrated in several animal models including primates (Stachel et al., 2006; Sankaranarayanan et al., 2009; May et al., 2011; Huang et al., 2012; Jeppsson et al., 2012).

Reports on BACE1 knock-out mice suggest that BACE1 is important during development and complete inhibition of BACE1 may result in side effects (Willem et al., 2006; Cai et al., 2012). These observations raise concerns whether complete inhibition of BACE1 in a chronic setting is safe and may have impli- 


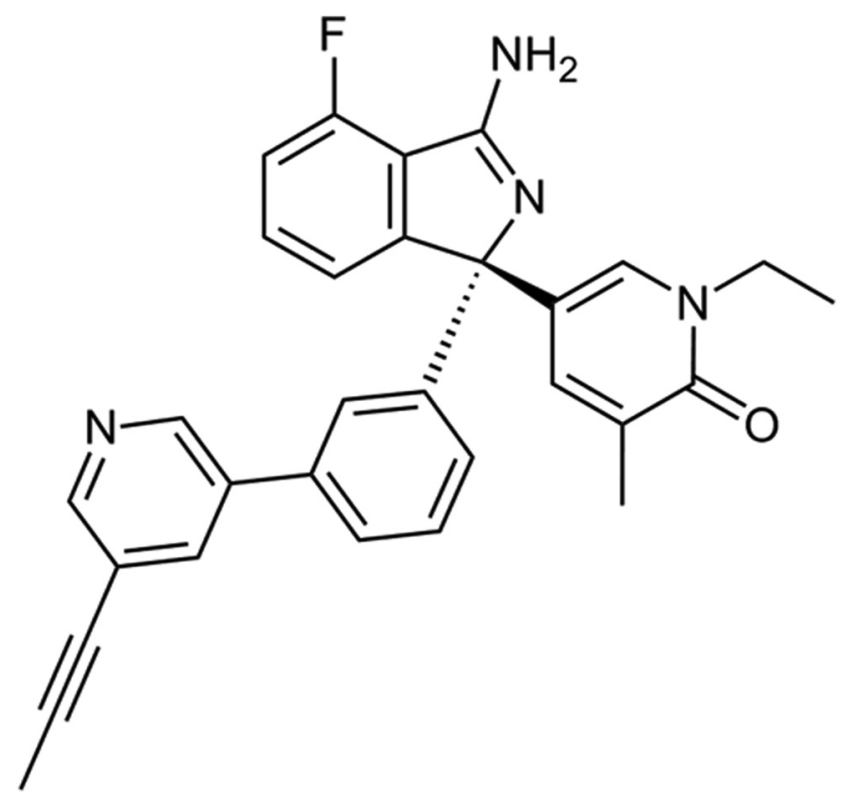

Figure 1. Structure of AZ-4217.

cations for the development of BACE1 inhibitors for therapeutic use. Several BACE1 inhibitors are currently in clinical development and have reported CSF A $\beta$ lowering in Phase I clinical studies (May et al., 2011; Forman et al., 2012; Lai et al., 2012). This is a promising first step to testing the potential of BACE1 inhibition as modifying the course of AD.

We report the discovery and pharmacological profile of a potent and selective, orally active, brain-permeable BACE1 inhibitor AZ-4217 with excellent in vivo efficacy. Central efficacy was observed after a single dose in three different animal models: mice, guinea pigs, and Tg2576 mice. Furthermore, we demonstrate that chronic treatment with AZ-4217 lowers amyloid deposition in 12-month-old Tg2576 mice.

\section{Materials and Methods}

Compound. The AZ-4217 was designed and synthesized at AstraZeneca $\mathrm{R} \& \mathrm{D}$ and the chemical structure is shown in Figure 1 (Swahn el al., 2012).

hBACE1 and hBACE2 TR-FRET assay. The procedure used has been described previously (Swahn et al., 2012). In short, the soluble part of the human $\beta$-secretase (recombinant hBACE1 enzyme, amino acids 1-460, or hBACE2 enzyme, amino acids 1-473) was mixed with compound in reaction buffer (Na-acetate, CHAPS, Triton X-100, EDTA, pH 4.5) and pre-incubated for $10 \mathrm{~min}$. Substrate (Europium)CEVNLDAEFK(Qsy7) (PerkinElmer) was added and the reaction was allowed to proceed for $6.5 \mathrm{~h}$ in darkness under lid at $22^{\circ} \mathrm{C}$ until stopped with the addition of $\mathrm{Na}$-acetate, $\mathrm{pH}$ 9. The fluorescence of the product was measured on a Wallac Victor II 1420 Multilabel Counter plate reader (PerkinElmer) with an excitation wavelength of $340 \mathrm{~nm}$ and an emission wavelength of $615 \mathrm{~nm}$.

hCathepsin D FRET assay. Cathepsin D enzyme (Calbiochem) and substrate (Ac-Glu-Asp(EDANS)-Lys-Pro-Ile-Leu-Phe-Phe-Arg-Leu-GlyLys(DABCYL)-Glu-NH2) (Bachem) were separately diluted in glycine-HCl buffer. Cathepsin D was mixed with compound dissolved in dimethylsulfoxide (DMSO) and pre-incubated for $10 \mathrm{~min}$. Substrate was added and the reaction mixture was incubated for $15 \mathrm{~min}$ in darkness at $22^{\circ} \mathrm{C}$. The fluorescent signal was measured on a Wallac Victor II 1420 Multilabel Counter plate reader (PerkinElmer) with an excitation wavelength of $355 \mathrm{~nm}$ and an emission wavelength of $460 \mathrm{~nm}$.

SH-SY5Y sAPP $\beta$ release assay. SH-SY5Y cells were cultured in DMEM/ F-12 with Glutamax, $10 \%$ fetal calf serum (FCS), and 1\% nonessential amino acids (Invitrogen). Compound was incubated with cells for $16 \mathrm{~h}$ at $37^{\circ} \mathrm{C}, 5 \% \mathrm{CO}_{2}$. MSD plates (Meso Scale Discovery) were used for the detection of sAPP $\beta$ release according to the manufacturer's instructions, and the plates were read in a SECTOR Imager. In addition, the cell plates were used to analyze cytotoxicity using the ViaLight Plus cell proliferation/cytotoxicity kit (Cambrex BioScience) according to the manufacturer's instructions.

SH-SY5Y A 340 release assay. SH-SY5Y cells overexpressing APP695wt were cultured in DMEM/F-12 with Glutamax, $10 \%$ FCS, and $1 \%$ nonessential amino acids (Invitrogen). The cells were incubated with cell culture media containing $\mathrm{AZ}-4217$ for $16 \mathrm{~h}$ at $37^{\circ} \mathrm{C}, 5 \% \mathrm{CO}_{2}$. Invitrogen ELISA strips KHB3482 were used for the detection of human A $\beta 40$ secreted into medium according to the manufacturer's instructions. The strips were read using a SpektraMax microplate reader (Molecular Devices).

Mouse primary neuron $A \beta 40$ release assay. Primary cortical cells were isolated from fetal C57BL/6 or Tg2576 mice (E16). The cortices were kept in calcium- and magnesium-free Earle's Balanced Salt Solution (EBSS; Invitrogen) containing $0.25 \%$ trypsin and $2 \mathrm{U} / \mathrm{ml}$ DNase for $1 \mathrm{~h}$ at $37^{\circ} \mathrm{C}$ and $5 \% \mathrm{CO}_{2}$. The cortices were washed in warm CMF-EBSS and gently triturated with flame-polished pipettes to separate the cells. The cell solution was transferred to a $50 \mathrm{ml}$ Falcon tube containing medium $(10 \%$ HamsF12; 10\% fetal bovine serum; 1\% 10 mм HEPES; $1 \% 2$ mM L-glutamine; $0.5 \% 50 \mathrm{U} / 0.5 \mathrm{mg}$ penicillin-streptomycin, and 77.5\% DMEM $\mathrm{w} / 4.5 \mathrm{~g} / \mathrm{L}$-glucose), and filtered through a $100 \mu \mathrm{m}$ Cell Strainer (BD Falcon). The cells were plated onto 96-well poly-D-lysine-coated plates at a density of 200,000 cells $/ 200 \mu \mathrm{l} /$ well. After $5 \mathrm{~d}$ at $37^{\circ} \mathrm{C}$ and $5 \% \mathrm{CO}_{2}$, the medium was changed to medium containing AZ-4217 and a final concentration of $1 \%$ DMSO. After incubation overnight, the amount of released $A \beta 40$ in the extracellular medium was measured using Invitrogen ELISA strips (KMB3481) according to the manufacturer's instructions. The strips were read using a SpektraMax microplate reader (Molecular Devices). The cytotoxic effect of compounds was directly evaluated on the cell plates using the ViaLight Plus cell proliferation/ cytotoxicity kit (Cambrex BioScience) according to the manufacturer's instructions.

Guinea pig primary neuron A $\beta 40$ release assay. Primary cortical cells from fetal Dunkin-Hartley guinea pigs (E25-E27) were prepared as described above. The amount of released $\mathrm{A} \beta 40$ in the extracellular medium was measured using Invitrogen ELISA strips (KHB3482) according to the manufacturer's instructions.

Animals and animal handling. Rodent experimentations were performed in accordance with relevant guidelines and regulations provided by the Swedish Board of Agriculture. The ethical permissions were provided by an ethical board specialized in animal experimentations (Stockholm North Animal Research Ethical Board). Female 10- to 18-week-old C57BL/6 mice (Harlan Laboratories) were used. The mice $(n=6)$ received vehicle or AZ-4217 at 25, 50, 100, or $200 \mu \mathrm{mol} / \mathrm{kg}(12 \mathrm{mg} / \mathrm{kg}, 24$ $\mathrm{mg} / \mathrm{kg}, 48 \mathrm{mg} / \mathrm{kg}$, or $95 \mathrm{mg} / \mathrm{kg}$ ) as a single dose via oral gavage. As vehicle, $5 \%$ dimethylacetamide and $20 \%$ hydroxypropyl- $\beta$-cyclodextrin $(\mathrm{HP} \beta C \mathrm{CD})$ in $0.3 \mathrm{~m}$ gluconic acid, $\mathrm{pH} 3$, alone was used. Male 5-week-old Dunkin-Hartley guinea pigs were purchased from HB Lidköping Kaninfarm (Sweden). The guinea pigs $(n=6)$ received vehicle or AZ-4217 at $25 \mu \mathrm{mol} / \mathrm{kg}, 50 \mu \mathrm{mol} / \mathrm{kg}$, or $100 \mu \mathrm{mol} / \mathrm{kg}(12,24$, and $48 \mathrm{mg} / \mathrm{kg})$ as a single dose via oral gavage. As vehicle, $0.3 \mathrm{~m}$ gluconic acid, $\mathrm{pH} 3$, was used. Tg2576 mice were purchased from Taconics, strain \#1349 B6; SJL Mixed Background, randomized upon arrival into different cages, and aged in the animal facility at AstraZeneca R\&D, Södertälje Sweden. The Tg2676 mice $(n=10-46), 12$-month-old at termination, received $200 \mu \mathrm{mol} / \mathrm{kg}$ $(95 \mathrm{mg} / \mathrm{kg}) \mathrm{AZ}-4217$ or vehicle ( $0.3 \mathrm{M}$ gluconic acid) as a single dose, or as repeated doses once daily during $7 \mathrm{~d}$ or $28 \mathrm{~d}$. Animals were anesthetized $0.5 \mathrm{~h}, 1.5 \mathrm{~h}, 3 \mathrm{~h}, 4.5 \mathrm{~h}, 8 \mathrm{~h}, 16 \mathrm{~h}$, or $24 \mathrm{~h}$ after first or final administration of vehicle or drug, and were then kept under isoflurane anesthesia. CSF was aspirated from the cisterna magna (guinea pigs) and plasma was isolated from blood collected by cardiac puncture into EDTA tubes. Animals were then killed by decapitation and brains were dissected into hemispheres. Moreover, female $\operatorname{Tg} 2576$ mice were also terminated at different ages between 3 and 24 months to be able to study the variation of $\operatorname{SAPP} \alpha$ and $\operatorname{sAPP} \beta_{\text {SWE }}$ with age.

Extraction and analysis of $A \beta$ and $s A P P$ in animal samples. The left brain hemispheres were sequentially extracted by diethylamine (DEA) 
followed by formic acid (FA), to obtain soluble and insoluble fractions of $\mathrm{A} \beta$ and sAPP species. C57BL/6 mouse and guinea pig brains were only extracted with DEA. In short brain tissue was homogenized/sonicated in $1: 18$ or $1: 20(\mathrm{w} / \mathrm{v}) 0.2 \% \mathrm{DEA}$ with $50 \mathrm{~mm} \mathrm{NaCl}$, followed by ultracentrifugation. Recovered supernatants (soluble $\mathrm{A} \beta$ ) were neutralized to $\mathrm{pH} 8.0$ with $2 \mathrm{~m}$ Tris-HCl. The remaining pellet was sonicated in 1:18 (w/v) $70 \%$ $\mathrm{FA}$, ultracentrifuged, and the recovered supernatants (insoluble $\mathrm{A} \beta$ ) were neutralized to $\mathrm{pH} 7.5$ with $1 \mathrm{M}$ Tris at 1:20 (w/v) dilution. For C57BL/ 6 samples, $A \beta 40$ and $A \beta 42$ levels in DEA brain extracts and $A \beta 40$ levels in plasma were analyzed using commercial $A \beta 1-40$ and $A \beta 1-42$ ELISA kits (KMB3481 and KMB3441; Invitrogen). sAPP $\beta$ in the DEA brain extracts were analyzed using MSD sAPP $\beta$ kit (K110BTE-2; Meso Scale Discovery). For guinea pig samples, $A \beta 40$ and $A \beta 42$ levels in DEA brain extracts, CSF, and plasma were analyzed using commercial A $\beta 1-40$ (KHB3482; Invitrogen) and A $\beta 1-42$ (80177 RUO; Innogenetics) ELISA kits. In the Tg2576 material transgenic human or mouse endogenous $A \beta 40$ and $A \beta 42$ concentrations in plasma, soluble (DEA) and insoluble (FA) fractions were measured by commercial sandwich ELISA kits, according to manufacturer's protocols (KHB3482, KMB3441, and KMB3481 from Invitrogen and RUO80177 from Innogenetics). The levels of sAPP $\beta_{\text {SWE }}$ and sAPP $\alpha$ in the soluble (DEA) fractions were measured using the MSD technology platform (K111BUE-2 and K111BSE-2; Meso Scale Discovery). All assays were validated inhouse and cross-reactivity between human and mouse $A \beta$-sequences were found to be negligible. To compensate for matrix effects, plasma or brain homogenates from nontransgenic mice were used for preparation of standard curves. The lower limit of quantification (LLOQ) was determined for each immunoassay plate based on the lowest standard point with a coefficient of variation $<20 \%$ and an accuracy (back-calculated concentrations) of $80-120 \%$. Analysis of data was done with pairwise comparisons as $t$ tests within a one-way ANOVA model on log transformed data, using Prism 4 (GraphPad). Level of significance was set at $p<0.05$ (two-tailed).

Bioanalysis of in vivo samples. The right brain hemisphere was homogenized in two volumes (w/v) of Ringer's solution. Aliquots of plasma (25 $\mu \mathrm{l})$ and brain homogenate $(50 \mu \mathrm{l})$ were precipitated with $150 \mu \mathrm{l}$ acetonitrile containing $200 \mathrm{nmol} / \mathrm{L}$ warfarin as a generic internal standard. Samples were mixed, centrifuged, diluted with mobile phase, and analyzed on an liquid chromatography/mass spectrometry (LC-MS/MS) system. CSF aliquots $(15 \mu \mathrm{l})$ were directly diluted and injected. Correction for blood content in brain was made by subtracting $1.3 \%$ of the plasma concentration from the total brain concentration.

Binding to plasma proteins and brain tissue. AZ-4217 was added to female C57BL/6 mouse or male Dunkin-Hartley guinea pig plasma to a final concentration of $10 \mu \mathrm{mol} / \mathrm{L}$. An aliquot was dialyzed against phosphate buffer and incubated for $18 \mathrm{~h}$ at $37^{\circ} \mathrm{C}$. Proteins were removed from $50 \mu \mathrm{l}$ aliquots of dialyzed plasma and buffer samples, internal standard was added, and the samples were analyzed with LC-MS/MS. The unbound fraction in plasma was calculated from the ratio of the MS area of AZ-4217 in buffer divided by sum of the areas of AZ-4217 in buffer and plasma. Recovery and stability in plasma were controlled for. Protein plasma binding for female Tg2576 mice was assumed to be comparable to that of $\mathrm{C} 57 \mathrm{BL} / 6$ mice.

To determine brain tissue binding, 300- $\mu \mathrm{m}$-thick coronal rat brain slices were incubated for $5 \mathrm{~h}$ in $10 \mathrm{ml}$ of an artificial interstitial fluid buffer containing $1 \mu \mathrm{M} \mathrm{AZ-4217.} \mathrm{Following} \mathrm{the} \mathrm{incubation,} \mathrm{slices} \mathrm{were}$ weighted and homogenized, proteins were removed, and LC-MS/MS analysis was performed. The unbound fraction in brain was calculated as described by Fridén et al., 2009. Mouse and guinea pig total brain concentrations were converted to free concentrations by multiplying with the unbound fraction. It has been shown that this unbound fraction in brain is interexchangeable between different species (Di et al., 2011).

Pharmacokinetic/pharmacodynamic analysis. Pharmacokinetic/pharmacodynamic (PK/PD) modeling was performed using WinNonlin (Version 5.2; Pharsight Corporation). A simultaneous fit for all doses of the PK profile in plasma or brain was performed per species/strain using a one-compartment PK model. Total brain concentrations were converted to free brain levels using brain exposure, plasma protein, and brain binding. $A \beta$ levels in treated animals were converted to values relative to
Table 1. AZ-4217 potency against BACE1, related aspartic proteases, and cellular APP processing assays

\begin{tabular}{|c|c|}
\hline & Results \pm SD \\
\hline \multicolumn{2}{|l|}{ Study } \\
\hline hBACE1 affinity, TR-FRET $\left(\mathrm{K}_{\mathrm{i}}\right)$ & $1.8 \pm 0.40 \mathrm{~nm}$ \\
\hline SH-SY5Y/APP, $A \beta 40$ readout $\left(\mathrm{IC}_{50}\right)$ & $200 \pm 54 \mathrm{pm}$ \\
\hline SH-SY5Y, SAPP $\beta$ readout $\left(\mathrm{IC}_{50}\right)$ & $160 \pm 110 \mathrm{pm}$ \\
\hline $\begin{array}{l}\text { C57BL/6 Mouse Primary Neurons, } A \beta 40 \\
\text { readout }\left(\mathrm{IC}_{50}\right)\end{array}$ & $2.7 \pm 0.82 \mathrm{~nm}$ \\
\hline $\begin{array}{l}\text { Tg2576 mouse primary neurons, } A \beta 40 \\
\text { readout }\left(\mathrm{IC}_{50}\right)\end{array}$ & $38 \pm 11 \mathrm{~nm}$ \\
\hline Guinea pig primary neurons, $A \beta 40$ readout $\left(I_{50}\right)$ & $2.0 \pm 1.3 \mathrm{~nm}$ \\
\hline \multicolumn{2}{|l|}{ Selectivity targets } \\
\hline hBACE2 affinity, TR-FRET $\left(\mathrm{K}_{\mathrm{i}}\right)$ & $2.6 \pm 0.86 \mathrm{~nm}$ (no sel. versus hBACE1) \\
\hline hCathepsin D affinity, TR-FRET $\left(\mathrm{K}_{\mathrm{i}}\right)$ & $25 \mu \mathrm{M}(>10,000 x$ sel. versus hBACE1) \\
\hline
\end{tabular}

Data are reported as mean \pm SD of at least four independent experiments (Cathepsin D only measured twice).

vehicle by calculation of the mean $A \beta$ level measured in vehicle-treated animals per experiment per time point followed by calculation of the $\mathrm{A} \beta$ levels in treated animals as percentage of vehicle mean. The fitted brain concentrations were used to drive an indirect response model with an assumed inhibition on the production rate $\left(k_{\text {in }}\right.$; Dayneka et al., 1993) to estimate the turnover rate of $\mathrm{A} \beta$ in brain $\left(k_{\text {out }}\right)$ and the concentration giving $20 \%$ inhibition from baseline of $\mathrm{A} \beta$ in brain $\left(\mathrm{IC}_{20}\right.$, including the time delay due to the $\mathrm{A} \beta$ turnover rate). The outcome of this fit was used to calculate the $\mathrm{IC}_{50}$ to allow direct comparison with in vitro models.

\section{Results}

\section{In vitro potency and selectivity}

The potency of AZ-4217 to inhibit human BACE1 and its closely related enzymes was evaluated in vitro (Table 1). AZ-4217 inhibited recombinant human BACE1 in a concentration-dependent manner, reaching $100 \%$ inhibition, with a $K_{i}$ of $1.8 \mathrm{nM}$. AZ-4217 inhibited the other isoform of BACE, human BACE2, with a $K_{i}$ of $2.6 \mathrm{nM}$. AZ-4217 showed more than a 10,000-fold selectivity against another aspartic protease, Cathepsin D $\left(K_{i}>25 \mu \mathrm{M}\right)$. In SH-SY5Y cells stably overexpressing wild-type APP695, AZ-4217 decreased the secretion of $\mathrm{A} \beta 40$ in a concentration-dependent manner with an $\mathrm{IC}_{50}$ of $200 \mathrm{pM}$. In wild-type SH-SY5Y cells AZ4217 decreased the secretion of sAPP $\beta$ with an $\mathrm{IC}_{50}$ of $160 \mathrm{pM}$. The potency difference between the enzymatic assay and the cell assays was expected as the substrate peptide in the TR-FRET assay carries the Swedish mutation $\left(\mathrm{APP}_{\mathrm{SWE}}\right)$ and the cells express wild-type APP. In a similar fashion AZ-4217 decreased the A $\beta 40$ levels secreted from primary cortical neurons from C57BL/6 mice, Tg2576 mice, and guinea pigs, resulting in $\mathrm{IC}_{50}$ values of 2.7, 38, and $2.0 \mathrm{~nm}$, respectively (Fig. 2). Hence, AZ-4217 was 14 times less potent in the Tg2576 primary cortical neurons compared with the C57BL/ 6 mouse cell assay, based on $\mathrm{A} \beta 40$ readout.

AZ-4217 was tested in a panel of 98 in vitro radioligand binding and enzyme assays, covering a diverse range of receptors, ion channels, transporters, and enzymes, up to a concentration of 10 $\mu \mathrm{M}$. A few significant hits were observed; however, these had at least a 2400-fold selectivity against BACE1, thus indicating specific binding to BACE (data not shown).

\section{Plasma protein and brain tissue binding}

The in vitro plasma protein binding of AZ-4217 was determined by equilibrium dialysis for both mouse and guinea pig. The unbound fractions were $1.5 \pm 0.3 \%$ and $0.87 \pm 0.15 \%$ for mouse and guinea pig, respectively (mean $\pm \mathrm{SD}$ ). AZ-4217 was found to be stable in plasma for at least $24 \mathrm{~h}$. The free fraction in brain tissue was $1 \%$. 


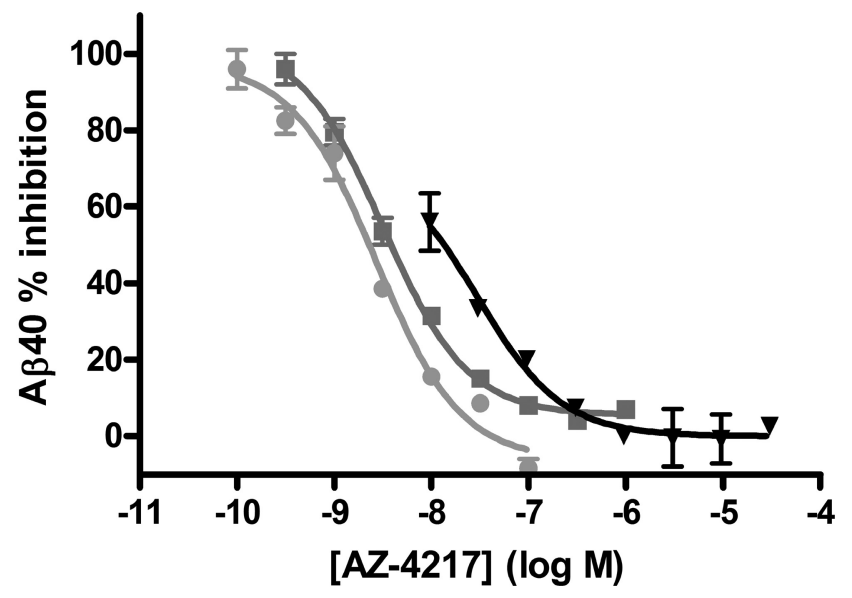

Figure 2. Concentration-dependent reduction of $A \beta 40$ generation in cortical primary neurons from guinea pig and $\mathrm{C57BL} / 6$ and $\operatorname{Tg} 2576$ mice. Concentration-dependent reduction of $A \beta 40$ generation in cortical primary neurons from guinea pig (filled circles), $C 57 \mathrm{BL} / 6$ (squares), and $\operatorname{Tg} 2576$ (triangles) mice, after AZ-4217 treatment. AZ-4217 completely inhibited the A $\beta 40$ production in the three cell systems, with the highest potency observed in the guinea pig cells. Data shown as mean \pm SEM.

\section{Concentration effect relationship of AZ-4217 in C57BL/6 mice}

To study the concentration effect relationship of AZ-4217 in vivo, the compound was orally dosed to C57BL/6 mice $(25 \mu \mathrm{mol} / \mathrm{kg}$, $50 \mu \mathrm{mol} / \mathrm{kg}, 100 \mu \mathrm{mol} / \mathrm{kg}$, or $200 \mu \mathrm{mol} / \mathrm{kg}$ ) followed by a PK/PD analysis. The simultaneous fit of the resulting PK profiles in plasma estimated an almost proportional increase in exposure with increased dose. Clearance was estimated to $0.73 \pm 0.05$ $\mathrm{L} / \mathrm{h} / \mathrm{kg}$ (estimate $\pm \mathrm{SE}$ on the estimate), volume to $5.7 \pm 0.3 \mathrm{~L} / \mathrm{kg}$, and the absorption rate constant to $3.7 \pm 1.0 \mathrm{~h}^{-1}$. The maximum concentration $\left(C_{\max }\right)$ in plasma was estimated to $1.0 \mathrm{~h}$ after dose (Fig. 3A). The PD effect readout was brain-soluble $A \beta 40 / 42$ and sAPP $\beta$ levels. Maximum reduction of brain $A \beta 40$ and $A \beta 42$ (Fig. $3 B, D$ ) occurred at a later time point than $C_{\max }$ in plasma and brain resulting in a hysteresis-loop in the concentration-effect relationship (Fig. 3C). Despite a tendency of the compound not to reach immediate brain plasma ratio equilibrium, the concentration in plasma had an almost linear relationship to the concentration in brain (Fig. 3E). The maximum effect on brain sAPP $\beta$ ( $29 \%$ reduction from vehicle) was observed $6 \mathrm{~h}$ after an acute 100 $\mu \mathrm{mol} / \mathrm{kg}$ dose of AZ-4217 (Fig. $3 F$ ). The PK parameter estimates of the compound in brain were used to simultaneously fit brain $\mathrm{A} \beta 40$ or $\mathrm{A} \beta 42$ levels relative to vehicle in time- and doseresponse profiles to estimate the in vivo potency and the turnover half-life of $\mathrm{A} \beta$. This half-life was estimated to $47 \mathrm{~min}$ for $\mathrm{A} \beta 40$ (Table 2) and $35 \mathrm{~min}$ for $\mathrm{A} \beta 42$, respectively. The $\mathrm{IC}_{50}$ free in brain was estimated to $4.7 \mathrm{~nm}$ for $\mathrm{A} \beta 40$ (Table 2) and $5.0 \mathrm{~nm}$ for $\mathrm{A} \beta 42$.

\section{$\mathrm{PK} / \mathrm{PD}$ relationship of $\mathrm{AZ}-4217$ in guinea pigs}

The dose-response effect of AZ-4217 on plasma, brain, and CSF $\mathrm{A} \beta$ in guinea pigs was investigated $3 \mathrm{~h}$ after an oral dose of 25 $\mu \mathrm{mol} / \mathrm{kg}, 50 \mu \mathrm{mol} / \mathrm{kg}$, or $100 \mu \mathrm{mol} / \mathrm{kg}$ and time-dependent effects were studied between 0.5 and $24 \mathrm{~h}$ after a $50 \mu \mathrm{mol} / \mathrm{kg}$ dose (Fig. 4). In the dose-response study, a clear effect on soluble A $\beta$ levels in plasma, brain, and CSF was observed. Plasma A $\beta 40$ seemed to have reached a $55-65 \%$ reduction regardless of dose at the $3 \mathrm{~h}$ time point, $\mathrm{A} \beta 42$ levels were reduced down to the lower limit of quantification of the ELISA assay even at the lowest dose, resulting in a $>90 \%$ reduction (Figs. $4 A, B$ ). AZ-4217 displayed a dose-dependent reduction of brain-soluble $\mathrm{A} \beta$ with a maximum estimated effect of 80 and $67 \%$, respectively, for $A \beta 40$ and $A \beta 42$ (Fig. $4 C, D$ ). As in brain, AZ-4217 inhibition of CSF A $\beta 40$ generation was dose dependent (Fig. $4 E$ ) with a maximum calculated effect of $67 \%$ at the highest dose. The time-dependent reduction of plasma, brain, and CSF A $\beta 40$ as well as AZ-4217 exposure in plasma and brain were evaluated in the time-response study (Fig. $4 F, G)$. Plasma $\mathrm{A} \beta 40$ reached maximum reduction $1.5 \mathrm{~h}$ after dose $(\sim 70 \%)$ and this reduction was sustained up until $8 \mathrm{~h}$ after dosing. After $16 \mathrm{~h} \mathrm{~A} \beta$ levels in plasma were still reduced to $\sim 50 \%$ of the vehicle-treated group, and even after $24 \mathrm{~h}$ had the $\mathrm{A} \beta 40$ levels in plasma not returned back to baseline. Sixteen hours after the $50 \mu \mathrm{mol} / \mathrm{kg}$ dose one of six guinea pigs had a plasma exposure below the LLOQ of $5 \mathrm{nM}$, while the remaining 5 had a mean exposure of $9.4 \pm 5.5 \mathrm{nM}$ (mean $\pm \mathrm{SD})$. Twenty-four hours after the oral dose of $50 \mu \mathrm{mol} / \mathrm{kg}$ none of the six guinea pigs had a plasma exposure above LLOQ. In brain, the time-dependent reduction of $\mathrm{A} \beta 40$ displayed maximum effect $3 \mathrm{~h}$ after dose $(\sim 70 \%)$, at $8 \mathrm{~h}$ after dose the effect was still significant ( $\sim 20 \%)$, but at $16 \mathrm{~h}$ levels were back to baseline. The time course of CSF $\mathrm{A} \beta 40$ followed that of brain $\mathrm{A} \beta 40$ as depicted in Figure $4 F$.

A simultaneous fit of the plasma exposure after an oral 25 $\mu \mathrm{mol} / \mathrm{kg}, 50 \mu \mathrm{mol} / \mathrm{kg}$, or $100 \mu \mathrm{mol} / \mathrm{kg}$ dose revealed a linear increase in exposure with dose between doses 50 and $100 \mu \mathrm{mol} /$ $\mathrm{kg}$. In contrast, the $25 \mu \mathrm{mol} / \mathrm{kg}$ dose had only a factor 0.4 of the expected plasma exposure. Using brain exposure PK profiles the turnover half-life of $\mathrm{A} \beta 40$ was estimated to $53 \mathrm{~min}$ (Table 2 ) and of $\mathrm{A} \beta 42$ to $65 \mathrm{~min}$ with an $\mathrm{IC}_{50}$ free in brain of $1.8 \mathrm{nM}$, for both.

\section{Inhibition of $\mathrm{A} \boldsymbol{\beta}$ generation in $\mathrm{Tg} 2576$ mice}

The effect of AZ-4217 on A $\beta$ deposition in brain was studied in 12 -month-old $\operatorname{Tg} 2576$ mice. Both the effects on transgenic human $A \beta(h A \beta)$ and endogenous mouse $A \beta(m A \beta)$ in the soluble (DEA extracted) and insoluble (FA extracted) pools were studied. Insoluble $A \beta$ is believed to come from $A \beta$ deposits but appears before $\mathrm{A} \beta$ plaques can be visualized by immunohistochemistry in brain from Tg2576 mice (Kawarabayashi et al., 2001). Funato et al. (1998) have further shown that insoluble A $\beta 42$ correlates very well with the amyloid burden in human brains and that the accumulation of insoluble $A \beta 42$ precedes that of visual plaques. Thus, biochemical evaluation of insoluble $\mathrm{A} \beta$ is a more sensitive way of quantitatively evaluating effects on $\mathrm{A} \beta$ deposition in animal with no or few plaques. Nontransgenic animal do not develop plaques and consequently no insoluble $\mathrm{A} \beta$ can be detected. We have, however, studied the accumulation of endogenous $\mathrm{mA} \beta$ with age in Tg2576 mice, which increases both in the soluble and the insoluble brain pools (K. Dillner-Bergstedt, A. Bogstedt, D. Sunnemark, P. Appelkvist, F.-H. Wang, M. Lindberg, S. Schött, B. Georgievska, H. Wigström, S. Eketjäll, and J. Sandin, manuscript in preparation); co-aggregation of $\mathrm{mA} \beta$ with hA $\beta$ has also been shown in transgenic mice overexpressing APP with the London mutation (Pype et al., 2003). Given the higher in vitro $\mathrm{IC}_{50}$ for $\mathrm{APP}_{\mathrm{SWE}}$, female Tg2576 mice (12 months at termination) were treated with $200 \mu \mathrm{mol} / \mathrm{kg} \mathrm{AZ}-4217$, acutely, $7 \mathrm{~d}$ or $28 \mathrm{~d}$ and terminated $4.5 \mathrm{~h}$ after last dose. In brain, reductions in soluble and insoluble hA $\beta 40$ and $\mathrm{A} \beta 42(\sim 20-30 \%, p<0.05)$ were only seen after $28 \mathrm{~d}$ of treatment (Fig. $5 A-D$ ). Interestingly, acute effects on the direct product of BACE1, sAPP $\beta_{\mathrm{SWE}}$, were clearly seen already after a single dose of AZ-4217, as well as elevation of sAPP $\alpha$ levels, and the effect levels remained the same independent of duration of treatment, confirming consistent inhibition of BACE1 in the brain throughout the period (Fig. $5 E$ ). We also studied the variation of the levels of $\operatorname{sAPP} \alpha$ and $\operatorname{sAPP} \beta_{\mathrm{SWE}}$ in 
A

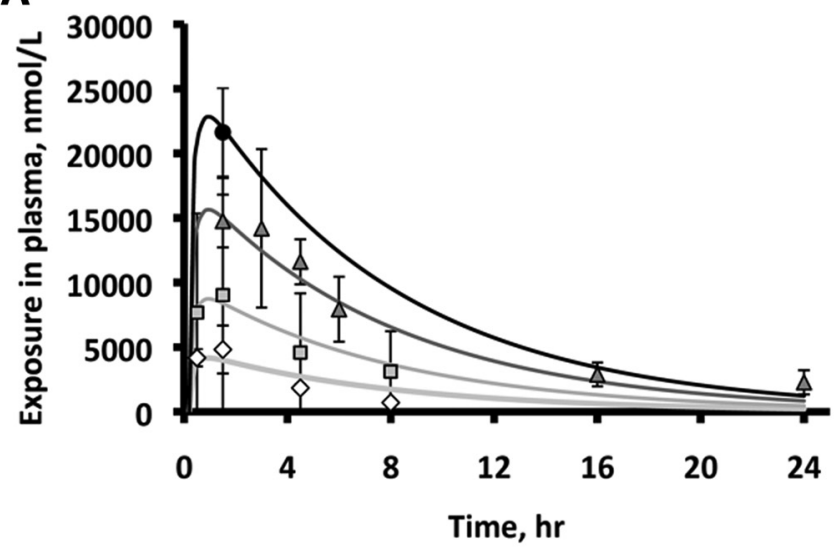

C

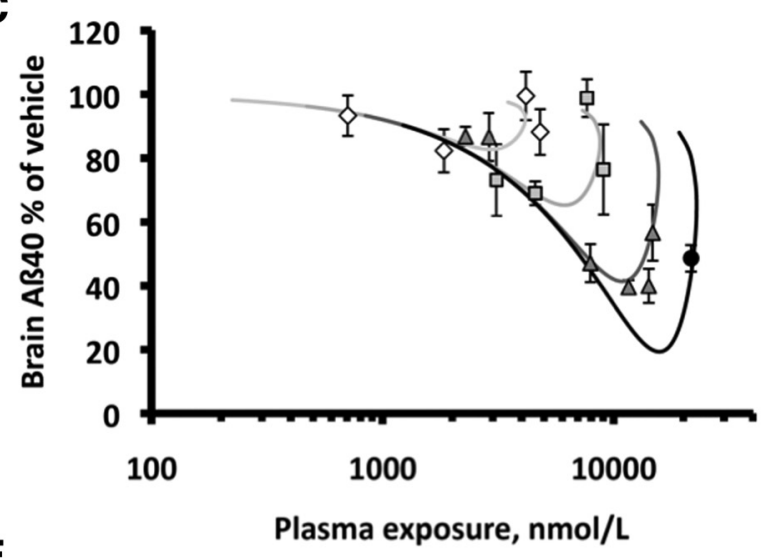

$\mathbf{E}$

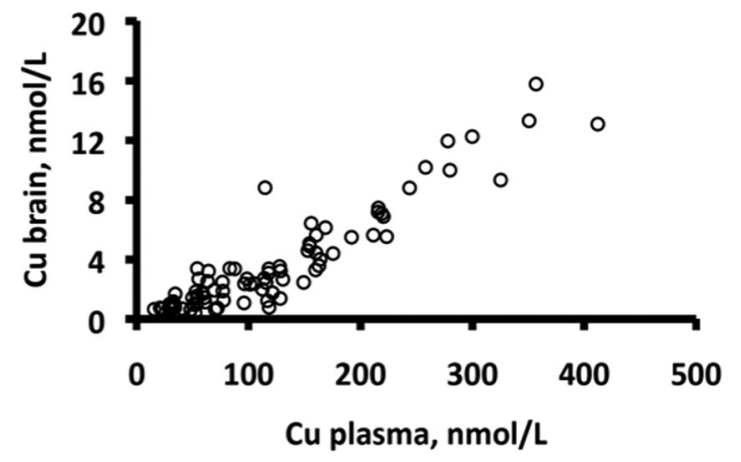

B

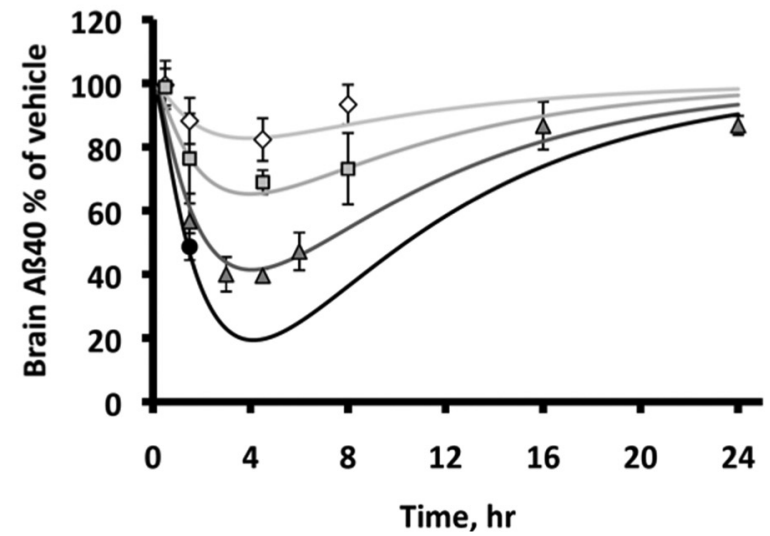

D

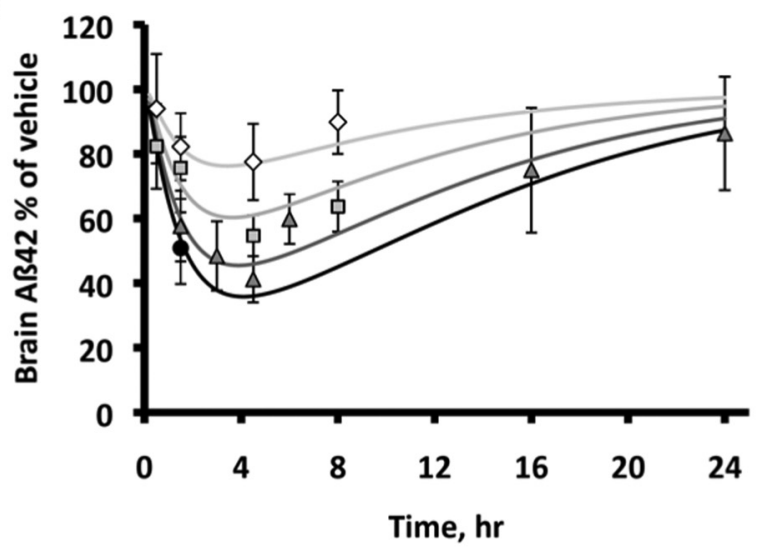

$\mathbf{F}$

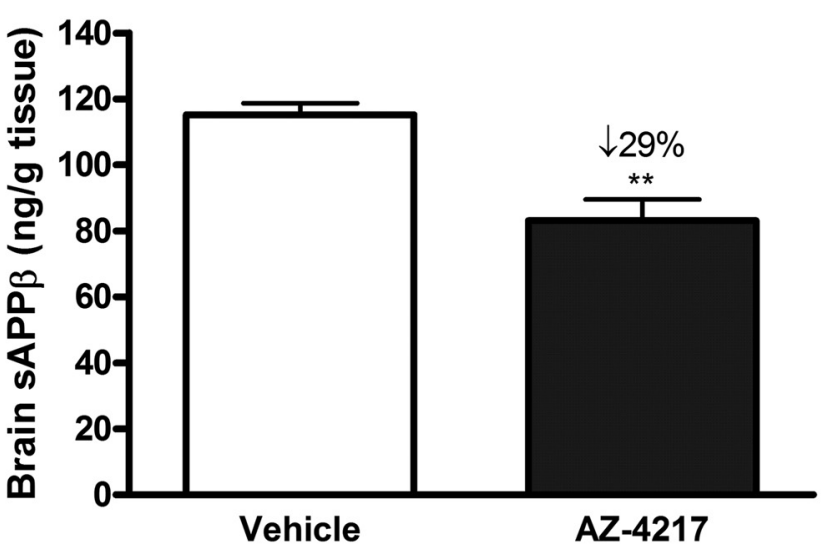

Figure 3. Time- and dose/concentration-dependent inhibition of A $\beta$ generation in plasma and brain of C57BL/ 6 mice. Time- and dose-dependent inhibition of $A \beta$ generation in $C 57 \mathrm{BL} / 6$ mice after a $25 \mu \mathrm{mol} / \mathrm{kg}$ (diamonds), $50 \mu \mathrm{mol} / \mathrm{kg}$ (squares), $100 \mu \mathrm{mol} / \mathrm{kg}$ (triangles), or $200 \mu \mathrm{mol} / \mathrm{kg}$ (filled circles) oral dose. Mean \pm SD observed and fitted time-plasma exposure profiles (A). Mean $\pm S D$ observed and fitted time-A $\beta 40$ in brain profiles (B). Plasma exposure versus observed mean $\pm S D$ and fitted $A \beta 40$ in brain (C). Mean $\pm S D$ observed and fitted time-A $A 42$ in brain profiles (D). Unbound plasma versus free brain concentrations as measured in individual mice at the different doses and time points $(\boldsymbol{E})$. Only values above LLOQ are shown, the mean levels $( \pm S E M$, $n=59$ ) of $A \beta 40$ and $A \beta 42$ in the vehicle-treated groups were $4352 \pm 136$ and $1072 \pm 31 \mathrm{pg} / \mathrm{g}$ tissue, respectively. The effect on SAPP $\beta$ was also studied and displayed maximum reduction at $6 \mathrm{~h}$ after a $100 \mu \mathrm{mol} / \mathrm{kg}$ dose $(\boldsymbol{F})$. Data are presented as mean values $\pm \operatorname{SEM}\left({ }^{* *} p<0.01\right.$, compared with vehicle).

Table 2. Exposure correlations in vitro/in vivo

\begin{tabular}{lllll}
\hline Species, strain & In vitro $\mathrm{IC}_{50}, \mathrm{nM}$ & Turnover half-life, min & In vivo $\mathrm{IC}_{20}, \mathrm{nM}$ & In vivo IC $\mathrm{I}_{50}, \mathrm{nM}$ \\
\hline Mouse, $\mathrm{C57BL} / 6$ & $2.7 \pm 0.82$ & $47(37-64)$ & $1.8(1.5-2.1)$ & 4.7 \\
Guinea pig, DH & $2.0 \pm 1.3$ & $53(34-121)$ & $0.5(0.3-0.7)$ & 1.8 \\
Mouse, Tg2576 & $38 \pm 11$ & $\mathrm{NA}$ & $\mathrm{NA}$ & $\mathrm{NA}$ \\
\hline
\end{tabular}

In vitro $\mathrm{IC}_{50}$ in primary neurons incubated with AZ-4217 ( \pm SD). Turnover half-life of A $\beta 40$ in brain ( $k_{\text {out }}$, estimate and $95 \%$ planar confidence interval). No turnover half-life could be determined in Tg2576 due to a single time point effect readout. In vivo $\mathrm{IC}_{20}$ is expressed as free $\mathrm{AZ}-4217$ concentration in brain (estimate and $95 \%$ planar confidence interval). Calculated in vivo $\mathrm{IC}_{50}$ for $A \beta 40$ in brain as free AZ-4217 concentration in brain.
DEA brain homogenates fromTg2576 mice and found them to be comparatively stable between the age of 3 and 24 months (Fig. $5 F$ ) Plasma hA $\beta 40$ was reduced down to the lower limit of quantification of the ELISA assay in all AZ-4217 Tg2576 treatment groups (data not shown). Moreover no acute effects were observed on endogenous $\mathrm{mA} \beta$ in the 12 -month-old Tg2576 mice. However, soluble brain $\mathrm{mA} \beta 40$ and $\mathrm{mA} \beta 42$ were, after $7 \mathrm{~d}$ of treatment, reduced $\sim 40 \%$ and $\sim 25 \%$, respectively (Fig. $6 A, B$ ), while insoluble $\mathrm{mA} \beta 40$ and $\mathrm{mA} \beta 42$ levels were only significantly different from vehicle after $28 \mathrm{~d}$ of treatment $(\sim 30 \%)$ (Fig. $6 C, D)$. After $28 \mathrm{~d}$ of treatment, 

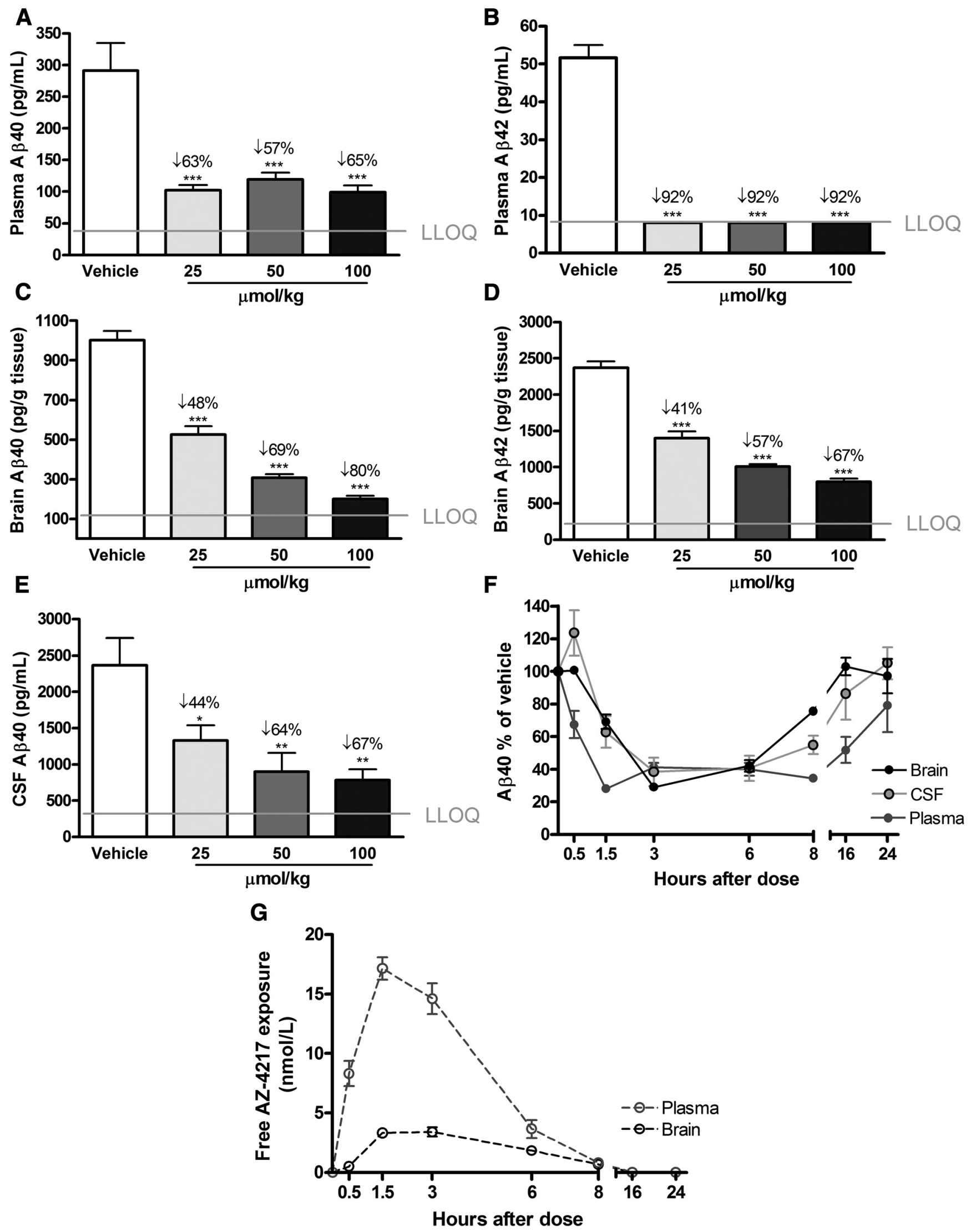

Figure 4. Time- and dose-dependent inhibition of $A \beta$ generation in guinea pig AZ-4217 was given to guinea pigs via oral gavage at doses $25 \mu \mathrm{mol} / \mathrm{kg}, 50 \mu \mathrm{mol} / \mathrm{kg}$, or $100 \mu \mathrm{mol} / \mathrm{kg}$ and effects were observed after $3 \mathrm{~h}(\boldsymbol{A}-\boldsymbol{E})$. Inhibition of plasma $A \beta 40(\boldsymbol{A})$ and $A \beta 42(\boldsymbol{B})$ seemed to reach a plateau, with $A \beta 42$ reduced down to the $L L 00$ of the assay. Brain $A \beta 40(\boldsymbol{C})$ and $A \beta 42(\boldsymbol{D})$ were reduced dose dependently. CSF $A \beta 40(\boldsymbol{E})$ also displayed a dose-dependent reduction. The time-response effects on brain, CSF, and plasma A $\beta 40$ (A $\beta 42$ not shown) of $A Z-4217$ were studied with 50 $\mu \mathrm{mol} / \mathrm{kg}(\boldsymbol{F})$, as well as the free concentration of AZ-4217 in plasma and brain $(\boldsymbol{G})$. Data are presented as mean values \pm SEM $\left({ }^{*} p<0.05 ;{ }^{* *} p<0.01,{ }^{* * *} p<0.001\right.$, compared with vehicle). 

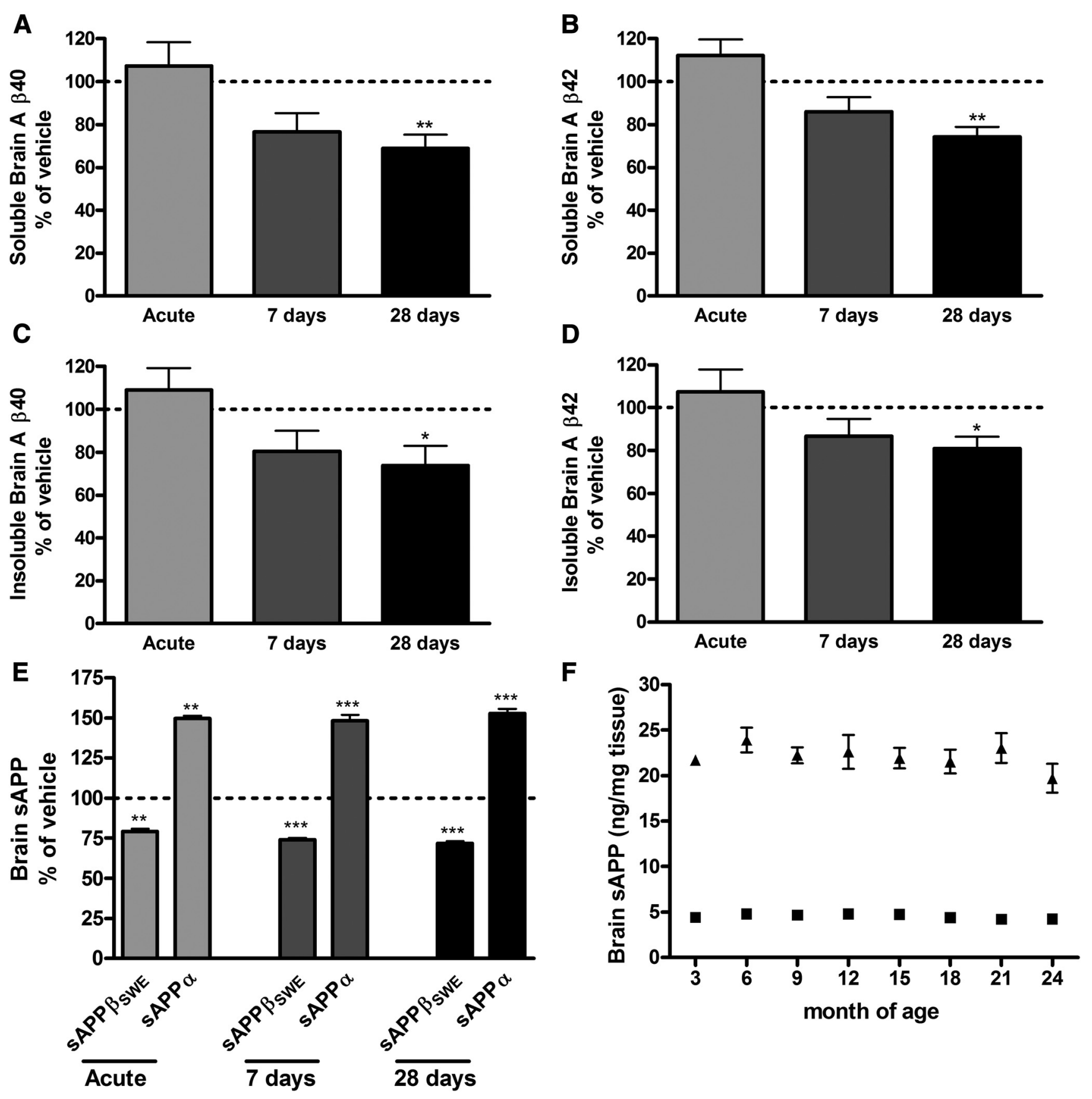

Figure 5. Acute and long-term treatment of $\mathrm{Tg} 2576$ mice with AZ-4217. Female $\operatorname{Tg} 2576$ (12 months at termination) mice were treated with $200 \mu$ mol/kg AZ-4217 acutely or repeatedly once daily for 7 and $28 \mathrm{~d}$, terminated $4.5 \mathrm{~h}$ after last dose. Significant effects on brain hA $\beta 40$ and hA $\beta 42$ were only seen after $28 \mathrm{~d}$ of treatment in both the soluble $(\boldsymbol{A}, \boldsymbol{B})$ and the insoluble $(\boldsymbol{C}, \boldsymbol{D})$ brain pools. Target engagement was seen already after acute treatment both on brain sAPP $\beta_{\text {SWE, }}$ reduced, and brain sAPP $\alpha$, elevated (E). The levels of sAPP $\beta_{\text {SWE }}$ (triangles) and sAPP $\alpha$ (squares) in DEA brain homogenates were stable in female Tg2576 mice between 3 and 24 months of age $(\boldsymbol{F})$. Data are presented as mean values \pm SEM $\left(^{*} p<0.05\right.$; ${ }^{* *} p<0.01,{ }^{* * *} p<0.001$, compared with vehicle). The mean levels (pg/mg tissue \pm SEM, $n=72 / 77$ ) in the vehicle-treated groups were $396 \pm 26$ (soluble hA $\beta 40$ ), $207 \pm 9$ (soluble hA $\beta 42$ ), $2399 \pm 193$ (insoluble hA $\beta 40$ ), and $2961 \pm$ 148 (insoluble hA $\beta 42$ ).

AZ-4217 exposure in plasma and brain was in line with the prediction made on the basis of the acute study performed in C57BL/6 mice as reported above.

\section{Discussion}

There is a great need for therapeutic interventions to stop/slow the progress of $\mathrm{AD}$. As a key target implicated in pathophysiology, drugs targeting amyloid production and/or clearance are currently pursued. The $\gamma$-secretase inhibitors and $\mathrm{A} \beta$ antibodies tested to date have failed to reach primary clinical endpoints, and so much emphasis has been put into developing BACE1 inhibitors or modulators of the $\gamma$-secretase complex as targets early in the production of $\mathrm{A} \beta$ (D'Onofrio et al., 2012; Probst et al., 2012; $\mathrm{Xia}$ at al., 2012). A general concern with targeting BACE1 or $\gamma$-secretase is that it may result in adverse target-related effects due to the involvement of these secretases in other signaling pathways (Vassar et al., 2009). The identity and full physiological importance of other BACE1 substrates in addition to APP are, 

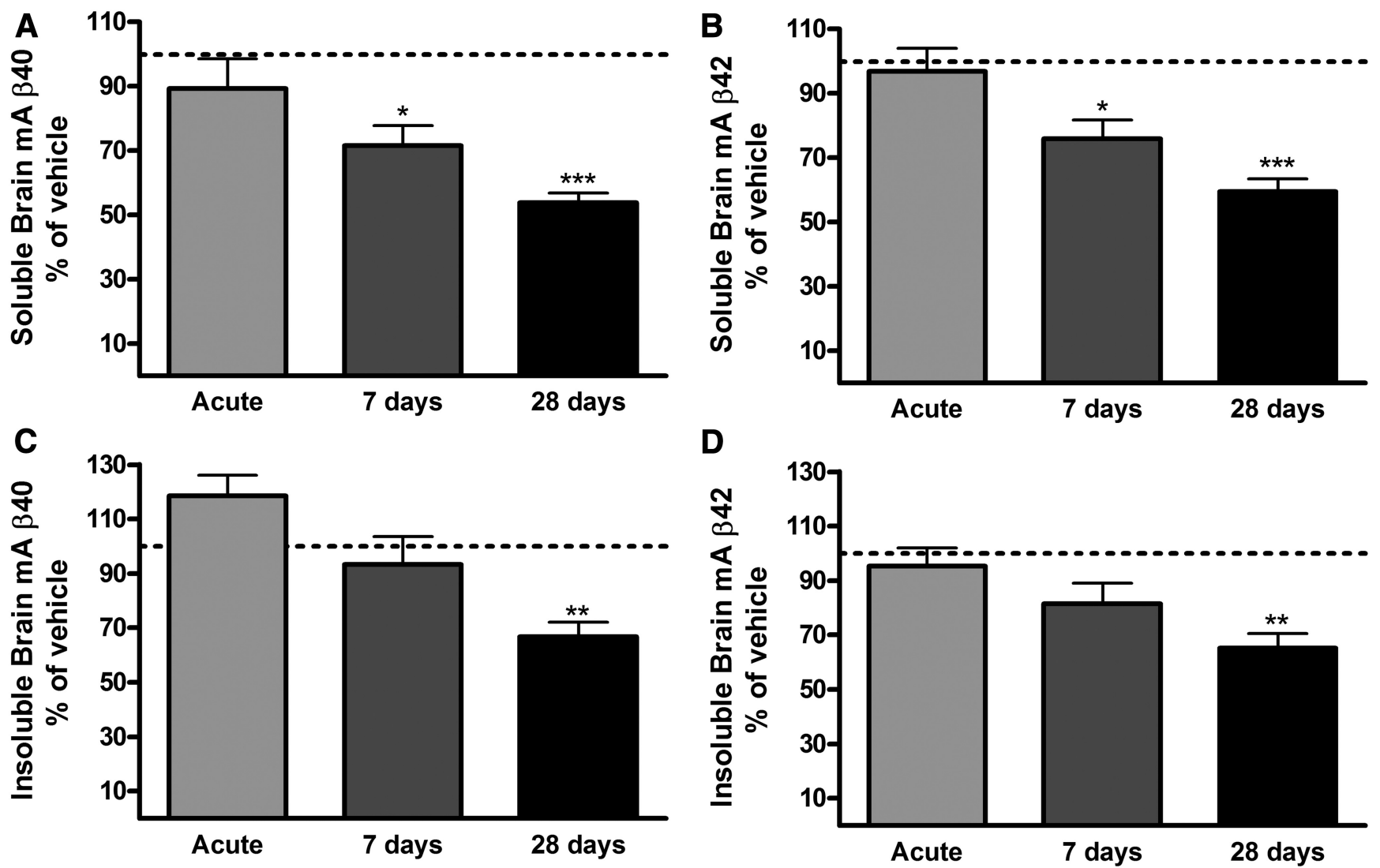

Figure 6. Effects on endogenous $m A \beta$ in 12-month-old Tg2576 mice treated with AZ-4217. In the same Tg2576 brain extracts, as hA $\beta$ were measured, we also evaluated the effects on endogenous $\mathrm{mA} \beta$. Significant reductions of soluble endogenous brain $\mathrm{mA} \beta 40$ and $\mathrm{mA} \beta 42$ were observed after $7 \mathrm{~d}$ of treatment $(\boldsymbol{A}, \boldsymbol{B})$. As with hA $\beta$-insoluble endogenous brain $\mathrm{mA} \beta 40$, hA $\beta 42$ only displayed significant effects after $28 \mathrm{~d}$ of treatment $(\boldsymbol{C}, \boldsymbol{D})$. Data are presented as mean values $\pm \mathrm{SEM}\left({ }^{*} p<0.05\right.$; ${ }^{* *} p<0.01,{ }^{* * *} p<0.001$, compared with vehicle). The mean levels (pg/mg tissue $\pm \mathrm{SEM}, n=77$ ) in the vehicle-treated groups were $8 \pm 0.5$ (soluble $\mathrm{mA} \beta 40$ ), $8 \pm 0.4$ (soluble $\mathrm{mA} \beta 42$ ), $53 \pm 3$ (insoluble $\mathrm{mA} \beta 40$ ), and $88 \pm 5$ (insoluble $\mathrm{mA} \beta 42$ ).

with few exceptions, largely unknown. However, a number of recent reports suggests that some of the functional aspects of BACE1 (conveyed by its substrates such as neuregulin, $\beta$-subunit of $\mathrm{Na}^{+}$channels, etc.) may be important, at least during development (Hu et al., 2006; Kim et al., 2011; Cai et al., 2012; Cao et al., 2012). Of note, most of the new information regarding the significance of BACE1 and its substrates for normal physiological function is derived from transgenic mouse work. However, the findings described in BACE1 knock-out mice could be characterized as a developmental phenotype that only manifested itself in homozygous knock-out animals, and thus pharmacologic inhibition of BACE1 in adult humans may have different manifestations. AZ-4217 displays similar inhibition of BACE1 and BACE2. In contrast to BACE1, BACE2 is expressed at very low levels in neurons and the role of BACE2 in APP processing and disease, or if inhibition of BACE2 would increase safety concerns, remains uncertain. An additional way forward to achieving an improved therapeutic efficacy safety window is to aim for compounds with very high affinity, thereby facilitating a low human dose and limiting offtarget-related safety concerns. There is, however, a risk that a highaffinity active site inhibitor could increase the potency against other potential substrates and, consequently, induce toxicity. Nevertheless, provided the high-affinity compound possesses good PK properties, the overall safety risk including idiosyncratic toxicity and offtarget toxicity should be reduced considering that the exposure required to achieve a therapeutic effect will be substantially lower compared with medium or poor affinity compounds.

The crystal structure of AZ-4217 in complex with BACE1 was reported previously (Swahn et al., 2012). The binding of AZ-4217 to BACE1 translates into a potent compound in human SH-SY5Y cells (160 pM) with an excellent in vivo efficacy profile in three different preclinical animal models. Wild-type C57BL/6 mice and guinea pigs, expressing endogenous APP and BACE1, were used for demonstration of efficacy of AZ-4217 on A $\beta$ levels in plasma, brain, and CSF in a native setting. The in vitro potency as observed in the primary neurons translated well to the in vivo potency in mouse.

Wild-type mice do not develop plaque. Therefore, in mice plaque burden is preferably studied in transgenic overexpressing models, which do develop amyloid plaques. One such model is the Tg2576 mouse model overexpressing human APP with the Swedish mutation $\left(\mathrm{APP}_{\mathrm{SWE}}\right)$, which develops amyloid plaques at 8-12 months of age (Hsiao et al., 1996; Kawarabayashi et al., 2001). To build confidence for efficacy in a disease setting, i.e., in addition to reducing soluble toxic species of $A \beta$ to also reducing $\mathrm{A} \beta$ deposition in brain, Tg2576 mice were used to study the efficacy of AZ-4217. BACE1 has a higher affinity for the APP ${ }_{S W E}$, which leads to increased APP processing and elevated levels of A $\beta$ peptides (Vassar et al., 1999). Thus, this mutation renders BACE1 inhibitors less potent in such systems, as is reflected in the 14-fold potency drop in cellular $\mathrm{IC}_{50}$ of $\mathrm{Tg} 2576$ relative to that of $\mathrm{C} 57 \mathrm{BL} / 6$ mice primary neurons. Aware of these constrains of the Tg2576 mouse model in evaluating a BACE1 inhibitor potency, both human $\mathrm{A} \beta$ (formed from overexpressed $\mathrm{APP}_{\mathrm{SWE}}$ ) and endogenous mouse $A \beta$ were measured. Significant effect on plasma $A \beta$ was shown already after a single dose of AZ-4217. Effect in brain was also observed after a single dose in form of brain 
sAPP $\beta_{\mathrm{SWE}}$ decrease, making the APP substrate available for $\alpha$-secretases leading to increased sAPP $\alpha$ levels. To our knowledge this is the first time BACE1 inhibition is demonstrated in the brain parenchyma after a single oral administration of a BACE1 inhibitor to Tg2576 mice. Noteworthy is also that the magnitude of the effect on both sAPP $\beta_{\text {SWE }}$ and sAPP $\alpha$ does not change with treatment length. Intriguingly, brain $A \beta 40 / 42$ reductions in this Tg2576 mouse model, independent of being endogenous or derived from the overexpressed human $\mathrm{APP}_{\mathrm{SWE}}$, only showed a reduction on soluble $A \beta 40 / 42$ after repeated dosing for $7 \mathrm{~d}$ and on insoluble $\mathrm{A} \beta 40 / 42$ when treated for $28 \mathrm{~d}$. These finding are in line with the observations made by Fukumoto et al. (2010) where they demonstrated effects on Tris-soluble $A \beta$ in the brain of young Tg2576 mice after 7 weeks of oral administration of a BACE1 inhibitor and on insoluble (FA) $A \beta$ in 13-month-old Tg2576 mice after 6 months of treatment. Chang et al. (2011) demonstrated effects on interstitial fluid $A \beta 40$ in young Tg2576 mice after an acute dose of a BACE1 inhibitor but only observed effects on brain extracts after long-term treatment. The difficulties of demonstrating acute effects on soluble brain $\mathrm{A} \beta$ in $\mathrm{Tg} 2576$ mice after a single administration of a BACE1 inhibitor has also been reported by others (Malamas et al., 2010). In contrast to what others have reported (Fukumoto et al., 2010) we do not see any changes in the levels of sAPP $\beta_{\mathrm{SWE}}$ or $\operatorname{SAPP} \alpha$, the direct products of BACE1 and $\alpha$-secretase activities, in female Tg2576 mice 3-24 months of age. Indicating that the activities of these enzymes are stable with age in Tg2576 mice. Accumulation of $A \beta$ in brain with age in $\mathrm{Tg} 2576$ mice and in $\mathrm{AD}$ patients is more likely to be the results of decreased transport and/or clearance of $\mathrm{A} \beta$ (Hartz et al., 2010; Mawuenyega et al., 2010). As observed in our studies BACE1 inhibition could therefore only manifest itself acutely in brain on SAPP $\beta_{\mathrm{SWE}}$ and not on soluble and insoluble $\mathrm{A} \beta$ in 12-month-old Tg2576 mice, where transport and/or clearance of $A \beta$ is reduced and the majority of extracted $A \beta$ comes from deposits, i.e., is not newly synthesized (Hong et al., 2011). Nevertheless, our data point to the concept that a BACE1 inhibitor can affect $A \beta$ deposition in brain after long-term treatment.

Although beyond the scope of the present study, it is worthwhile to note that treatment with AZ-4217 was very well tolerated throughout the study and did not produce any noticeable adverse effects, presumably because of the high target selectivity of the AZ-4217 and the low systemic burden that was enabled by the high affinity of the compound toward BACE1.

In summary, we present the discovery and pharmacological profile of AZ-4217, a novel BACE1 inhibitor with high potency in in vitro and in vivo systems. Furthermore, we demonstrate that in a 1 month treatment paradigm BACE1 inhibition of $A \beta$ production does lower amyloid deposition in brain of 12-month-old Tg2576 mice. In these mice BACE1 inhibition was confirmed already after a single dose, while effects on soluble and insoluble brain $\mathrm{A} \beta$ were only observed after repeated dosing. Choosing the right in vivo model and the right biomarker for preclinical screening is therefore of upmost importance. Our results strongly support BACE1 inhibition as effective for reduction of soluble toxic $\mathrm{A} \beta$ species and for lowering plaque deposition over time, hence potentially as a useful therapeutic intervention in an appropriate $\mathrm{AD}$ population.

\section{References}

Ballard C, Gauthier S, Corbett A, Brayne C, Aarsland D, Jones E (2011) Alzheimer's disease. Lancet 377:1019-1031. CrossRef Medline

Cai J, Qi X, Kociok N, Skosyrski S, Emilio A, Ruan Q, Han S, Liu L, Chen Z, Bowes Rickman C, Golde T, Grant MB, Saftig P, Serneels L, de strooper B,
Joussen AM, Boulton ME (2012) $\beta$-Secretase (BACE1) inhibition causes retinal pathology by vascular dysregulation and accumulation of age pigment. EMBO Mol Med 4:980-991. CrossRef Medline

Cao L, Rickenbacher GT, Rodriguez S, Moulia TW, Albers MW (2012) The precision of axon targeting of mouse olfactory sensory neurons requires the BACE1 protease. Sci Rep 2:231. Medline

Chang WP, Huang X, Downs D, Cirrito JR, Koelsch G, Holtzman DM, Ghosh AK, Tang J (2011) $\beta$-Secretase inhibitor GRL-8234 rescues age-related cognitive decline in APP transgenic mice. FASEB J 25:775-784. CrossRef Medline

Citron M, Oltersdorf T, Haass C, McConlogue L, Hung AY, Seubert P, VigoPelfrey C, Lieberburg I, Selkoe DJ (1992) Mutation of the beta-amyloid precursor protein in familial Alzheimer's disease increases beta-protein production. Nature 360:672-674. CrossRef Medline

Dayneka NL, Garg V, Jusko WJ (1993) Comparison of four basic models of indirect pharmacodynamic responses. J Pharmacokinet Biopharm 21: 457-478. CrossRef Medline

Di L, Umland JP, Chang G, Huang Y, Lin Z, Scott DO, Troutman MD, Liston TE (2011) Species independence in brain tissue binding using brain homogenates. Drug Metab Dispos 39:1270-1277. CrossRef Medline

D’Onofrio G, Panza F, Frisardi V, Solfrizzi V, Imbimbo BP, Paroni G, Cascavilla L, Seripa D, Pilotto A (2012) Advances in the identification of $\gamma$-secretase inhibitors for the treatment of Alzheimer's disease. Expert Opin Drug Discov 7:19-37. CrossRef Medline

Forman M., Palcza J, Tseng J, Leempoels J, Ramael S, Han D, Jhee S, Ereshefsky L, Tanen M, Laterza O, Dockendorf M, Krishna G, Ma L, Wagner J, Troyer M (2012) The novel BACE inhibitor MK-8931 dramatically lowers cerebrospinal fluid $\mathrm{Ab}$ peptides in healthy subjects following singleand multiple-dose administration. ICAD conference abstract. Alzheimers Dement 8:704. CrossRef

Fridén M, Ducrozet F, Middleton B, Antonsson M, Bredberg U, Hammarlund-Udenaes M (2009) Development of a high-throughput brain slice method for studying drug distribution in the central nervous system. Drug Metab Dispos 37:1226-1233. CrossRef Medline

Fukumoto H, Takahashi H, Tarui N, Matsui J, Tomita T, Hirode M, Sagayama M, Maeda R, Kawamoto M, Hirai K, Terauchi J, Sakura Y, Kakihana M, Kato K, Iwatsubo T, Miyamoto M (2010) A noncompetitive BACE1 inhibitor TAK-070 ameliorates $\mathrm{A} \beta$ pathology and behavioral deficits in a mouse model of Alzheimer's Disease. J Neurosci 30:1115711166. CrossRef Medline

Funato H, Yoshimura M, Kusui K, Tamaoka A, Ishikawa K, Ohkoshi N, Namekata K, Okeda R, Ihara Y (1998) Quantitation of amyloid betaprotein (A beta) in the cortex during aging and in Alzheimer's disease. Am J Pathol 152:1633-1640. Medline

Hardy J, Selkoe DJ (2002) The amyloid hypothesis of Alzheimer's disease: progress and problems on the road to therapeutics. Science 297:353-356. CrossRef Medline

Hartz AM, Miller DS, Bauer B (2010) Restoring blood-brain barrier P-glycoprotein reduces brain amyloid-beta in a mouse model of Alzheimer's disease. Mol Pharmacol 77:715-723. CrossRef Medline

Hong S, Quintero-Monzon O, Ostaszewski BL, Podlisny DR, Cavanaugh WT, Yang T, Holtzman DM, Cirrito JR, Selkoe DJ (2011) Dynamic analysis of amyloid $\beta$-protein in behaving mice reveals opposing changes in ISF versus parenchymal $\mathrm{A} \beta$ during age-related plaque formation. J Neurosci 31:15861-15869. CrossRef Medline

Hsiao K, Chapman P, Nilsen S, Eckman C, Harigaya Y, Younkin S, Yang F, Cole G (1996) Correlative memory deficits, Abeta elevation, and amyloid plaques in transgenic mice. Science 274:99-102. CrossRef Medline

Huang H, La DS, Cheng AC, Whittington DA, Patel VF, Chen K, Dineen TA, Epstein O, Graceffa R, Hickman D, Kiang YH, Louie S, Luo Y, Wahl RC, Wen PH, Wood S, Fremeau RT Jr (2012) Structure- and property-based design of aminooxazoline xanthenes as selective, orally efficacious, and CNS penetrable BACE inhibitors for the treatment of Alzheimer's disease. J Med Chem 55:9156-9169. CrossRef Medline

Hu X, Hicks CW, He W, Wong P, Macklin WB, Trapp BD, Yan R (2006) Bace1 modulates myelination in the central and peripheral nervous system. Nat Neurosci 9:1520-1525. CrossRef Medline

Jeppsson F, Eketjäll S, Janson J, Karlström S, Gustavsson S, Olsson LL, Radesäter AC, Ploeger B, Cebers G, Kolmodin K, Swahn BM, von Berg S, Bueters T, Fälting J (2012) J Biol Chem 287:41245-41257.

Jonsson T, Atwal JK, Steinberg S, Snaedal J, Jonsson PV, Bjornsson S, Stefansson H, Sulem P, Gudbjartsson D, Maloney J, Hoyte K, Gustafson A, Liu Y, 
Lu Y, Bhangale T, Graham RR, Huttenlocher J, Bjornsdottir G, Andreassen OA, Jönsson EG, et al. (2012) A mutation in APP protects against Alzheimer's disease and age-related cognitive decline. Nature 488:96-99. CrossRef Medline

Kawarabayashi T, Younkin LH, Saido TC, Shoji M, Ashe KH, Younkin SG (2001) Age-dependent changes in brain, CSF, and plasma amyloid (beta) protein in the Tg2576 transgenic mouse model of Alzheimer's disease. J Neurosci 21:372-381. Medline

Kim DY, Gersbacher MT, Inquimbert P, Kovacs DM (2011) Reduced sodium channel $\mathrm{Na}(\mathrm{v}) 1.1$ levels in BACE1-null mice. J Biol Chem 286: 8106-8116. CrossRef Medline

Lai R, Albala B, Kaplow JM, Aluri J, Yen M, Satlin A (2012) First-in human study of E2609, a novel BACE1 inhibitor, demonstrates prolonged reductions in plasma $\beta$-amyloid levels after single dosing. Alzheimer Dement 8:96. CrossRef

Malamas MS, Robichaud A, Erdei J, Quagliato D, Solvibile W, Zhou P, Morris K, Turner J, Wagner E, Fan K, Olland A, Jacobsen S, Reinhart P, Riddell D, Pangalos M (2010) Design and synthesis of aminohydantoins as potent and selective human $\beta$-secretase (BACE1) inhibitors with enhanced brain permeability. Bioorg Med Chem Lett 20:6597-6605. CrossRef Medline

Mawuenyega KG, Sigurdson W, Ovod V, Munsell L, Kasten T, Morris JC, Yarasheski KE, Bateman RJ (2010) Decreased clearance of CNS betaamyloid in Alzheimer's disease. Science 330:1774. CrossRef Medline

May PC, Dean RA, Lowe SL, Martenyi F, Sheehan SM, Boggs LN, Monk SA, Mathes BM, Mergott DJ, Watson BM, Stout SL, Timm DE, Smith Labell E, Gonzales CR, Nakano M, Jhee SS, Yen M, Ereshefsky L, Lindstrom TD, Calligaro DO, et al. (2011) Robust Central. Reduction of amyloid-b in humans with an orally available, non-peptidic $\beta$-secretase inhibitor. J Neurosci 31:16507-16516. CrossRef Medline

McConlogue L, Buttini M, Anderson JP, Brigham EF, Chen KS, Freedman SB, Games D, Johnson-Wood K, Lee M, Zeller M, Liu W, Motter R, Sinha S (2007) Partial reduction of BACE1 has dramatic effects on Alzheimer plaque and synaptic pathology in APP transgenic mice. J Biol Chem 282: 26326-26334. CrossRef Medline

Probst G, Xu YZ (2012) Small-molecule BACE1 inhibitors: a patent literature review (2006-2011). Expert Opin Ther Pat 22:511-540. CrossRef Medline

Pype S, Moechars D, Dillen L, Mercken M (2003) Characterization of amyloid beta peptides from brain extracts of transgenic mice overexpressing the London mutant of human amyloid precursor protein. J Neurochem 84:602-609. CrossRef Medline

Roberds SL, Anderson J, Basi G, Bienkowski MJ, Branstetter DG, Chen KS,
Freedman SB, Frigon NL, Games D, Hu K, Johnson-Wood K, Kappenman KE, Kawabe TT, Kola I, Kuehn R, Lee M, Liu W, Motter R, Nichols NF, Power M, et al. (2001) BACE knock-out mice are healthy despite lacking the primary beta-secretase activity in brain: implications for Alzheimer's disease therapeutics. Hum Mol Genet 10:1317-1324. CrossRef Medline

Sankaranarayanan S, Holahan MA, Colussi D, Crouthamel MC, Devanarayan V, Ellis J, Espeseth A, Gates AT, Graham SL, Gregro AR, Hazuda D, Hochman JH, Holloway K, Jin L, Kahana J, Lai MT, Lineberger J, McGaughey G, Moore KP, Nantermet P, et al. (2009) First demonstration of cerebrospinal fluid and plasma $A \beta$ lowering with oral administration of a $\beta$-site amyloid precursor protein-cleaving enzyme 1 Inhibitor in nonhuman primates. J Pharmacol Exp Ther 328:131-140. CrossRef Medline

Stachel SJ, Coburn CA, Sankaranarayanan S, Price EA, Wu G, Crouthamel M, Pietrak BL, Huang Q, Lineberger J, Espeseth AS, Jin L, Ellis J, Holloway MK, Munshi S, Allison T, Hazuda D, Simon AJ, Graham SL, Vacca JP (2006) Macrocyclic inhibitors of $\beta$-secretase: functional activity in an animal model. J Med Chem 49:6147-6150. CrossRef Medline

Swahn BM, Kolmodin K, Karlström S, von Berg S, Söderman P, Holenz J, Berg S, Lindström J, Sundström M, Turek D, Kihlström J, Slivo C, Andersson L, Pyring D, Rotticci D, Öhberg L, Kers A, Bogar K, Bergh M, Olsson L, et al. (2012) Design and synthesis of $\beta$-site amyloid precursor protein cleaving enzyme (BACE1) inhibitors with in vivo brain reduction of $\beta$-amyloid peptides. J Med Chem 55:9346-9361. CrossRef Medline

Vassar R, Bennett BD, Babu-Khan S, Kahn S, Mendiaz EA, Denis P, Teplow DB, Ross S, Amarante P, Loeloff R, Luo Y, Fisher S, Fuller J, Edenson S, Lile J, Jarosinski MA, Biere AL, Curran E, Burgess T, Louis JC, et al. (1999) Beta-secretase cleavage of Alzheimer's amyloid precursor protein by the transmembrane aspartic protease BACE. Science 286:735-741. CrossRef Medline

Vassar R, Kovacs DM, Yan R, Wong PC (2009) The beta-secretase enzyme BACE in health and Alzheimer's disease: regulation, cell biology, function, and therapeutic potential. J Neurosci 29:12787-12794. CrossRef Medline

Willem M, Garratt AN, Novak B, Citron M, Kaufmann S, Rittger A, DeStrooper B, Saftig P, Birchmeier C, Haass C (2006) Control of peripheral nerve myelination by the $\beta$-secretase BACE1. Science 314:664666. CrossRef Medline

Xia W, Wong ST, Hanlon E, Morin P (2012) $\gamma$-Secretase modulator in Alzheimer's disease: shifting the end. J Alzheimers Dis 31:685-696. Medline 